\title{
714 摺動性樹脂と金属複合無潤滑崡車の開発と解析・設計法
}

\section{Analysis and Design of Composite Gear Consisting of Resin and Steel without Lubrication}

\author{
李英（群馬大院） \\ 正 長屋 幸助（群馬大） \\ ○保 宏道 (群馬大院)
}

Ying LI, Gunma University, Tenjinchou1, Kiryuusi, Gunma

Kosuke NAGAYA, Gunma University

Koudou KUBO, Gunma University

\begin{abstract}
Recently, low noise gears without lubrication are required for business machines and robots, because they are used in open space. The present article provides a new type gear consisting of steel and resin (called Delrin-100), which has good lubrication characteristics. Production processes are presented for the gear, and its characteristics are investigated. It is ascertained that the strength of our gear is greater than that of a plastic gear, and noise of our gear is small in comparison with plastic gears. The design method is presented, and effects of friction on the position control is also investigated.
\end{abstract}

Key Words : Gear, Dry Friction, Composite Gear, Delrin-100, Design, Strength, Sound Noise, Control Error.

\section{A1 緒言}

現在使用されている歯車は歯面同士の直接接触によって菌面 の摩耗が進行し、振動や騒音が発生するといら久点があるため、 潤滑が必要である。しかし、近年コンピュータ機器などの增加 により、低騒音で無潤滑の歯車の開発が急務である。今日、無 潤滑歯車としてプラスチック菊車が用いられているが、駆動速 度を増大した場合、プラスチック歯車は比較的摩擦が大きいた め、歯面摩擦により歯面温度が上昇し変形が起こるのみならず、 接触部の摩耗が大きくなり、騒音や振動が増大する。その上強 度的にも弱い。

本研究では、摺動性がよくかつ衝撃にも強い樹脂である Delrin-100 に注目し、これをコア材とし、その両端を金属で接 着支持する複合樹脂歯車を提案する (図 A 1 の写真参照)。本 歯車を用いる場合、通常回転時に以樹脂歯と相手側金属歯車と が接触して回転し、大きな衝揧がかかった場合等には、金属歯 形で衝撃に耐えるといら構造である。本歯車の妥当性を検証す るため、実際に複合歯車を製作し、強度、騒音、摩擦などの観 点から理論的および実験的検討を行い、現在用いられているプ ラスチック歯車との比較検討を行う。

\section{A2 複合歯車の騷音特性}

本研究で提案した歯車を用いた場合の騷音の比較を行った。 以下歯車の組み合わせは一方が鋼製歯車で、他方がプラスチッ $ク(\mathrm{PS})$ 歯車（無潤滑）（Fe-PS）、本複合歯車（無潤滑）( FeDelrin)として、騒音の比較を行う。

図 A2 に，これらの歯車を回転数 $10 \mathrm{rps}$ で 100 時間回転 させた時の騒音の変化を示す。プラスチック歯車は終始 一定の䭽音である。一方、複合歯車の場合は回転し始め ると間もなく騒音が減少し、その後少し騒音が大きくな るが、それからまた徐々に騷音が減少していき、最終的 に一定の騒音に近づくということが分かる。また、100 時間回転後の騒音は、複合歯車の方が PS 歯車より約 $10 \mathrm{~dB}$ 小さいことが分かる。

\section{A3 複合歯車の強度}

本複合歯車の強度を調べるために、破壊䒠験を行った。その結 果、複合歯車の破断卜ルクは $483.5 \mathrm{~N} \cdot \mathrm{m}$ でプラスチック歯車の破 断トルクは $121.0 \mathrm{~N} \cdot \mathrm{m}$ であり、複合歯車は PS歯車より4 倍の強度 があることが分かった。

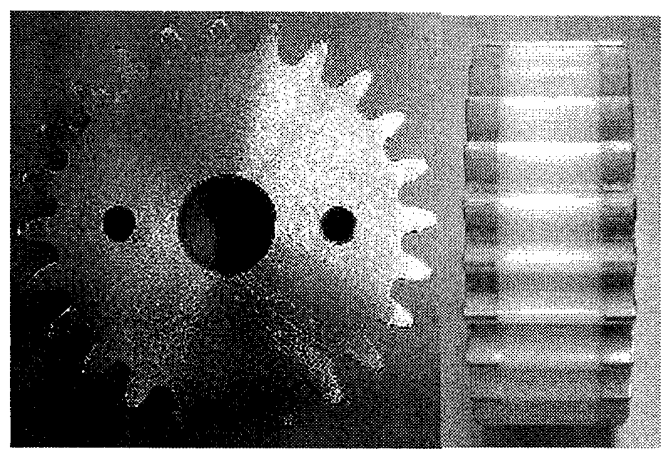

Fig_Al Composite gear made in this study

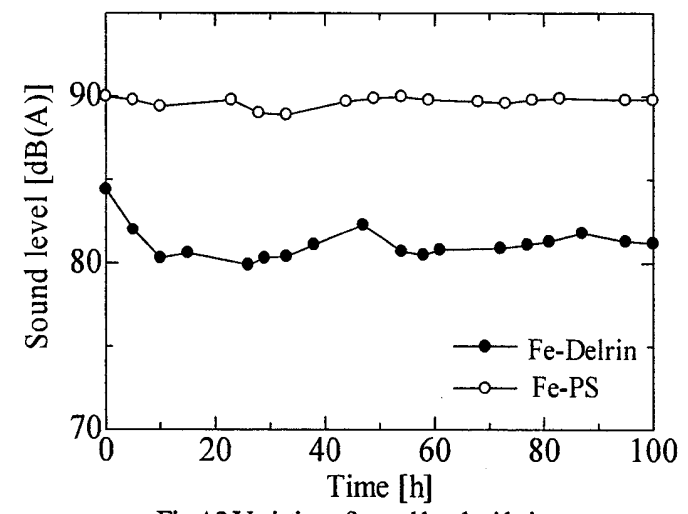

Fig.A2 Variation of sound level with time 


\section{1. 腥言}

現在使用されている歯車は歯面同士の直接接触によって歯面 の摩耗が進行し、振動や騒音が発生するという欠点があるため、 潤滑が必要である。しかし、近年コンピュータ機器など，人間 の居住する空間に置かれ、潤滑による環境污染が極度に嫌われ る機器が急速に増加している。そのため、低騒音で無潤滑の歯 車の開発が急務である。今日、無潤滑歯車としてプラスチック 菌車が用いられているが、駆動速度を増大した場合、プラスチ ック歯車は比較的摩擦が大きいため、歯面摩擦により歯面温度 が上昇し変形が起こるのみならず、接触部の摩耗が大きくなり、 騒音や振動が増大寸る。その上強度的にも弱い。そこで、本研 究室の長屋らは、潤滑特性の良い COPNA 樹脂を用いて、COPNA 歯車を製作した。この COPNA 歯車はプラスチック歯車に比べ騒 音が小さく、使用時間の経過とともに騒音が減少し、ある一定 の状態に近づくなどの特徵を有するが、実用化を考えると、強 度的にはやや弱く、衝撃にも弱いという久点があった。

そこで本研究では、大きな衝撃にも耐えうる Dehin-100 樹脂 と金属による複合歯車を提案する。実際に複合歯車を製作し、 強度、騷音、摩擦などの観点からプラスチック歯車と理論的お よび実験的に比較検討を行う。

\section{2. 歯車の製作法}

これまでの研究で、金属歯車と摺動性樹脂歯車を噛み合わ せて回転させたときは、周波数の高い耳障りな騒音が抑制され ることが分かっている。しかし、長屋らの開発した歯車には、 強度的に弱いという久点があった。そこで、金属歯と樹脂歯を 接触回転させて、騷音を抑制し、強度的に強い画車を作るため、 摺動性樹脂歯の両端を金属歯と接着させる方法を考える。この とき、金属歯と樹脂歯が同じ寸法のときは両端の金属歯が相手 方の金属歯に接触するので、その接触を無くする方法として、 両端の金属歯には負の転位を施し、内部（コア）の歯車を標準 歯車とすることを考える。

図 1 は上記の観点より設計された金属部の歯車を表す（以 下外歯車と称する）。本研究では、転位量を一 0.6 としてある。

平歯車

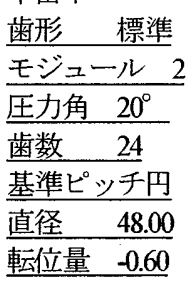
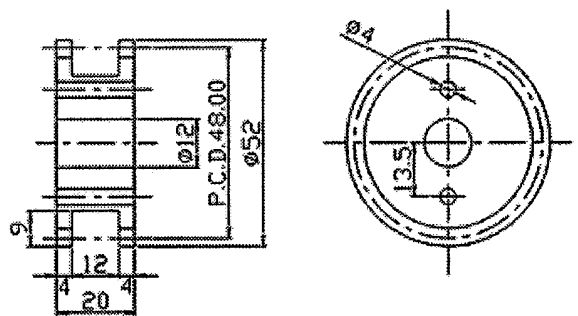

Fig.1 Design of outer gear

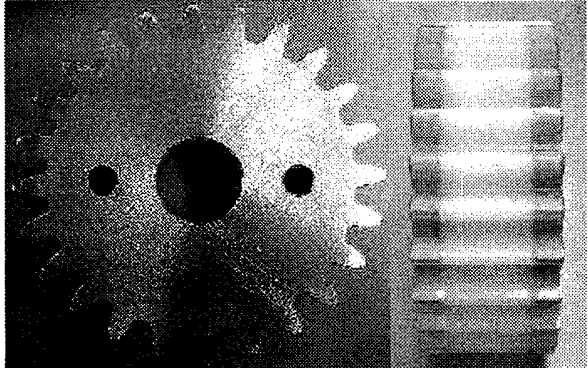

Fig.2 Composite gear made in this study

\section{3. 䙂合歯車の強度}

3.1 歯面のすべりを考慮した設計

本歯車では、樹脂の部分のみが相手方金属歯車と接触して回 転する。樹脂（Derin-100）には塑性域がほとんど無く、弾性域 のあと、突然破断する性質がある。そのため、金属歯車のよう な塑性変形を基準とする面圧設計法は適当ではない。本歯車の 場合は無潤滑であるため、すべり速度 $v$ と歯に作用する力 $F$ を用いた $F v$ 值による設計が適当と思われる。

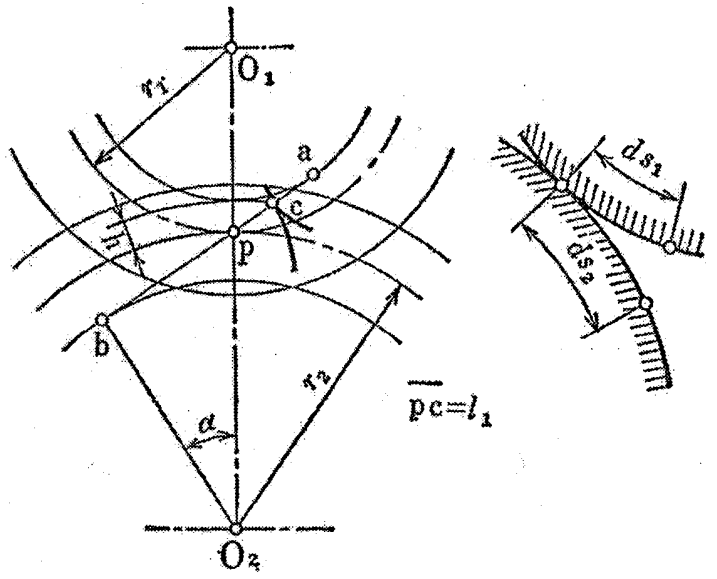

Fig.3 Sliding rate

一つの歯に作用する荷重を $P$ 、樹脂部分の幅を $b_{\mathrm{p}}$ とすると、 一つの歯の歯幅方向単位長さに作用する力 $F$ は、

$$
\begin{aligned}
& F=\frac{P}{b_{p}} \\
& \text { すべり速度 } v \text { は、 } \\
& v=\frac{1}{2}\left(-v_{1}+v_{2}\right)=\frac{1}{\tau}\left(-s_{1}+s_{2}\right) \\
& \text { ここに、 } \\
& v_{2}=2 s_{2} / \tau \quad v_{2}=2 s_{2} / \tau \\
& s_{1}=\left\{\left(r_{1} \sin \alpha-l_{1}\right)-\frac{r_{1}}{r_{2}}\left(r_{2} \sin \alpha+l_{1}\right)\right\}\left(\frac{\pi}{Z}\right) \\
& s_{2}=\left\{\left(r_{1} \sin \alpha+l_{2}\right)-\frac{r_{1}}{r_{2}}\left(r_{2} \sin \alpha-l_{2}\right)\right\}\left(\frac{\pi}{Z}\right) \\
& l_{1}=\sqrt{\left(r_{2}+h\right)^{2}-r_{2}^{2} \cos ^{2} \alpha}-r_{2} \sin \alpha
\end{aligned}
$$




$$
\begin{aligned}
l_{2} & =\sqrt{\left(r_{1}+h\right)^{2}-r_{1}^{2} \cos ^{2} \alpha}-r_{1} \sin \alpha \\
\tau & : \text { 一枚の歯が噛み合い始めてから噛み合い終了までの } \\
& \text { 時間 }
\end{aligned}
$$

設計では、上式により速度v を計算し、歯に作用する歯幅方 向単位長さ当たりの力 $F[N / m] と v[\mathrm{~m} / \mathrm{s}]$ の乗算 $F v$ の值が、複合歯車に用いた樹脂材料の $F v$ 值より小さい ように設計すれば良い。

\section{2 歯型検査}

Table 1 Variation of teeth profiles after rotation (Rotation speed $=900 \mathrm{rpm}$ )

\begin{tabular}{|c|c|c|c|c|c|}
\hline & $\begin{array}{c}\text { Torque } \\
{[\mathrm{Nm}]}\end{array}$ & $\begin{array}{c}\text { Rotaion } \\
\text { Time } \\
{[\text { Hour] }}\end{array}$ & $\begin{array}{c}\text { IS-gade } \\
\text { Before rotation } \\
\text { [LeftandRigitr] }\end{array}$ & $\begin{array}{c}\text { JS-grade } \\
\text { Affer rotation } \\
\text { [Leff] }\end{array}$ & $\begin{array}{c}\text { IS-grade } \\
\text { Affer rotation } \\
\text { [Right] }\end{array}$ \\
\hline Plastic Gear & 6 & 6.3 & 3 & Broken & Broken \\
\hline \multirow{2}{*}{$\begin{array}{c}\text { Composite } \\
\text { Gear }\end{array}$} & 6 & 24 & 3 & 5 & 3 \\
\cline { 2 - 6 } & 8.5 & 16 & 3 & 8 & 6 \\
\cline { 2 - 6 } & 12 & 18.5 & 3 & 8 & 5 \\
\hline
\end{tabular}

複合歯車の幾つかの場合について、負荷トルクを与えた後に 歯形検査を行った。検査結果を表 1 に示す。

表 1 に表されるように、プラスチック歯車では、 $6 \mathrm{~N} \cdot \mathrm{m}$ の負 荷トルク、900rpm の回転速度の下では、わずか 6.3 時間で歯が 破断している。一方、複合歯車の場合、 $\mathrm{N} \cdot \mathrm{m}$ の負荷トルク、 900 pm の回転速度で回転させるときは、磨耗粉は全く発生せ ず、24 時間回転させても、特に音の変化も、目視による歯形 の変化についても異常は認められなかった。本歯車は、回転速 度が $900 \mathrm{~mm}$ のとき、 $\mathrm{N} \cdot \mathrm{m}$ 程度の負荷トルクが限界值と考えら れる。この範囲では、前述のように、若干の歯形変化はあるが、 磨耗粉の発生が全く見られない。また温度についても計測して いるが、歯面摩擦による温度は最大で $50^{\circ} \mathrm{C}$ 程度であり、本樹 脂歯車の熱変形温度 $136^{\circ} \mathrm{C}$ よりるかに小さい。

上記限界値の場合、ピッチ点に作用する荷重は $250 \mathrm{~N}(=6 \times$ 1000/24）であり、一つの歯に作用する荷重は $\mathrm{P}=155 \mathrm{~N}(250 / \varepsilon$ $=155 \mathrm{~N})$ である。したがって歯幅方向単位長さに作用する荷重 は、樹脂部分の幅 $b_{\mathrm{p}}=12 \mathrm{~mm}$ を用いて、次の值となる。

$$
F=\frac{P}{b_{p}}=\frac{155}{12}=13[\mathrm{~N} / \mathrm{mm}]=13000[\mathrm{~N} / \mathrm{m}]
$$

すべり速度 $v$ は、

$$
\begin{aligned}
& v=\frac{1}{\tau}\left(-s_{1}+s_{2}\right)=\frac{1}{0.00278}(0.685+0.685) \\
& =0.492[\mathrm{~m} / \mathrm{s}]
\end{aligned}
$$

したがってこのときの $F v$ 值は

$$
F v=13000 \times 0.492=6396 \approx 6400[N / s]
$$

本複合歯車は、Delin 樹脂を複合するときは $F v=6400[\mathrm{~N} / \mathrm{s}]$ として、設計することができる。もちろんこの值は限界值であ るので、実際の設計では、安全率を見込む必要がある。

\section{3 複合歯車の接着強度設計}

樹脂歯が金属歯から剥がれることなく、樹脂歯と金属歯が 一体となって破断した。このときの破断荷重（12505[N]）は磨 耗時の限界荷重 $(155[\mathrm{~N}])$ に比べてはるかに大きい。すなわち、 本複合歯車の樹脂歯の設計は磨耗設計で決定されることになる。

\section{4 複合歯のたわみおよび応力}

樹脂歯の接着トルクが作用トルクより大きいとき、樹脂歯と 金属歯は一体となって変形する。本解析では、金属歯の部分を 歯高方向にテーパ状をなしたはりと考え、また樹脂歯む便宜上 テーパはりと考えて解析する(図 4 参照)。

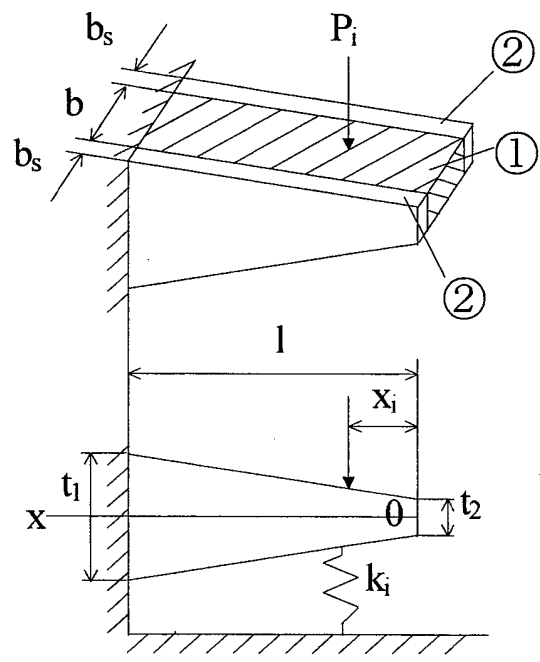

Fig4 Analytical model

複合歯の変位は

$$
y(x)=P_{i}\left\{C_{1}\left(1-\frac{x}{l}\right)^{2}+C_{2}\left(\frac{x}{l}\right)\left(1-\frac{x}{l}\right)^{2}\right\}
$$

ここに、

$$
\begin{aligned}
& C_{1}=\frac{\left(1-\frac{x_{i}}{l}\right)^{2}\left\{2 \alpha_{3}-\alpha_{2}\left(\frac{x_{i}}{l}\right)\right\}}{\left(4 \alpha_{1} \alpha_{3}-\alpha_{2}^{2}\right)} \\
& C_{2}=\frac{\left(1-\frac{x_{i}}{l}\right)^{2}\left\{2 \alpha_{1}\left(\frac{x_{i}}{l}\right)-\alpha_{2}\right\}}{\left(4 \alpha_{1} \alpha_{3}-\alpha_{2}^{2}\right)} \\
& \alpha_{1}=\frac{b E B_{1}}{24 l^{3}}+\frac{1}{2} k_{i}\left(1-\frac{x_{i}}{l}\right)^{4} \\
& \alpha_{2}=\frac{b E B_{2}}{6 l^{3}}+k_{i}\left(1-\frac{x_{i}}{l}\right)^{4}\left(\frac{x_{i}}{l}\right)^{4} \\
& \alpha_{3}=\frac{b E B_{3}}{24 l^{3}}+\frac{1}{2} k_{i}\left(1-\frac{x_{i}}{l}\right)^{4}\left(\frac{x_{i}}{l}\right)^{2}
\end{aligned}
$$

樹脂歯車に作用するモーメントは、

$$
M(x)=\frac{b E P_{i}}{12}\left\{t_{2}+\frac{\left(t_{1}-t_{2}\right) x}{l}\right\}^{3}\left\{C_{1}\left(\frac{2}{l^{2}}\right)+C_{2}\left(-\frac{4}{l^{2}}+\frac{6 x}{l^{3}}\right)\right\}
$$


よって歯の表面応力 $\sigma$ は、

$$
\left.\therefore \sigma=\frac{E}{2} P_{i}\left\{t_{2}+\frac{\left(t_{1}-t_{2}\right) x}{l}\right\} C_{1}\left(\frac{2}{l^{2}}\right)+C_{2}\left(-\frac{4}{l^{2}}+\frac{6 x}{l^{3}}\right)\right\}
$$

となる。

本複合歯車の利点を明確にするため、樹脂歯のみの場合と複 合菌車について、たわみおよび応力を比較する。まず Delrin 材 の樹脂歯のみの応力を本計算式により求めたものが、図 5 の破 線である。複合歯車の Delrin 樹脂歯の応力分布を実線で示す。 図から本複合歯車の応力は同じ寸法の樹脂歯のみに比べ $1 / 30$ 程度に抑制されており、鋼と摺動樹脂の複合により、強度的に も極めて大きな効果を期待できることが分かる。

図 6 は本複合歯車と Delrin-100 材のみの歯のときのたわみ分 布の比較を示したものである。Delrin-100 材のみで歯を作った ときの歯先変位は約 $30 \mu \mathrm{m}$ 程度に対し、本複合歯車の歯先変 位はその1/30の $1 \mu \mathrm{m}$ 程度に抑制されている。

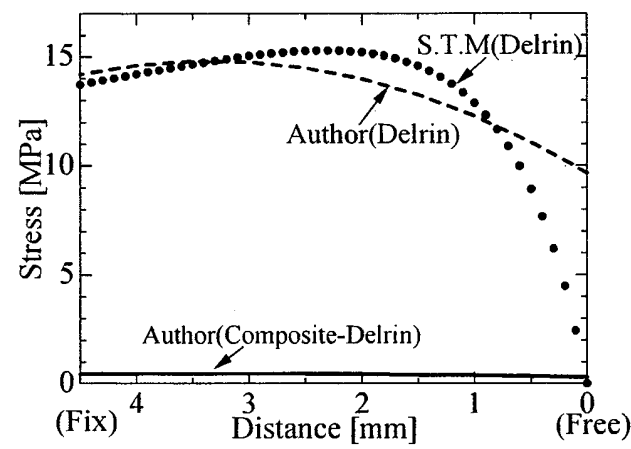

Fig.5 Stress distribution in Delrin gear teeth

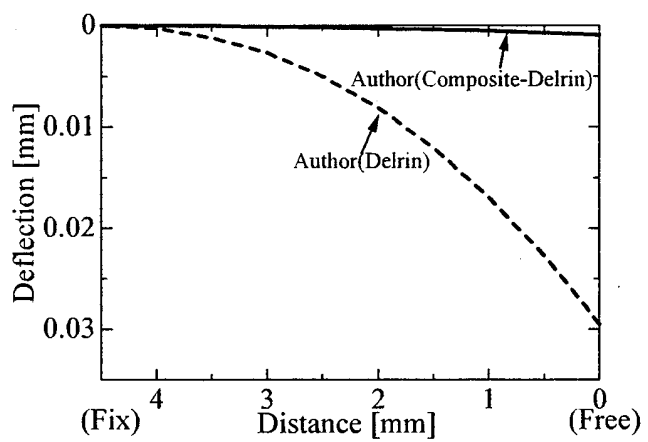

Fig.6Deflection of the gear teeth

\section{4. 複合歯車の騒音特性}

\section{1 騒音}

本研究で提案した歯車を用いた場合の騒音の比較を行った。 図 7、8 は騒音（C 特性）の時刻歴応答を示したものである。 回転前の複合歯車の騒音は、鋼製歯車に比べて少し大きいが、 プラスチック歯車に比べ明らかに小さいことが認められる。ま た回転前と 100 時間後の騒音を比較すると、プラスチック歯車 は 100 時間後の騷音にあまり変化がないのに対し、複合歯車は 100 時間後の騒音が明らかに小さくなっている事が分かる。
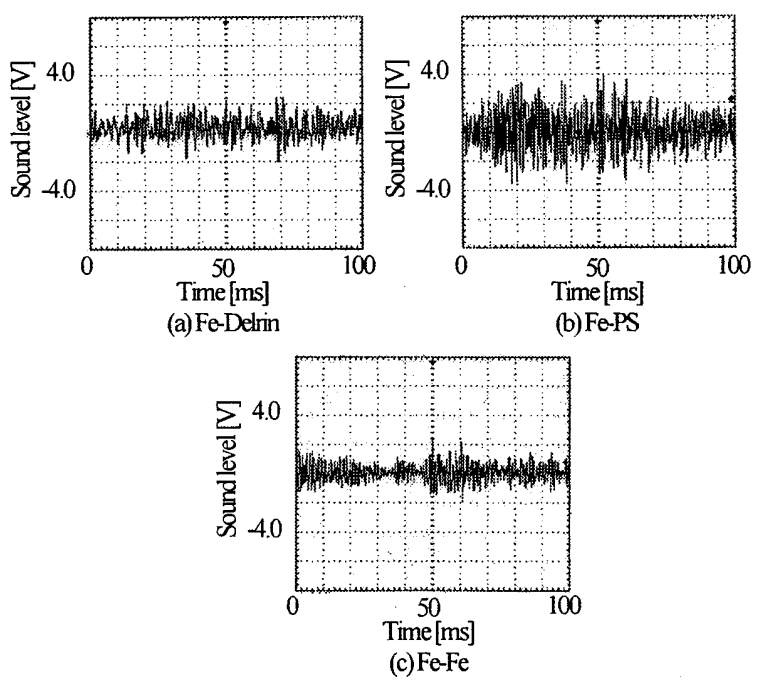

Fig 7 Time response of sound level (Rotation frequency $=10 \mathrm{rps}$ )

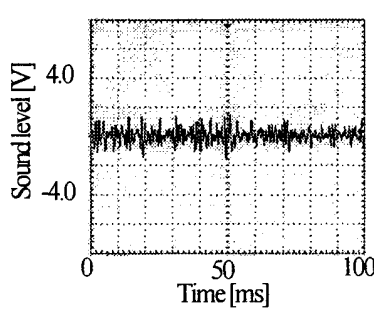

(a) Fe-Delrin (100hlater) (b) Fe-PS (100hlater)

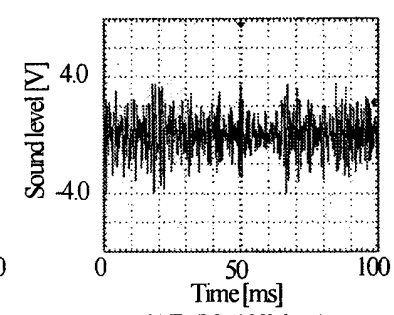

Fig.8 Time response of sound level (Rotation frequency $=10 \mathrm{rps}$ )

図 9に新しい蒾車の騒音 (A 特性) の測定結果を示す。いず れも回転数の増加とともに騒音が増加しており、その騒音特性 に大きな違いは見られない。

図 10 に，これらの歯車を回転数 $10 \mathrm{ps}$ で 100 時間回転させた 時の騒音の変化を示す。プラスチック歯車は終始一定の騒音で ある。一方、複合歯車の場合は回転し始めると間もなく騒音が 減少し、その後少し騒音が大きくなるが、それからまた徐々に 騒音が減少していき、最終的に一定の騒音に近づくということ がわかる。

図 11 に 100 時間回転後の騒音の測定結果を示す。いずれの 場合も回転数の増加とともに騒音が増加しており、騒音の差に 回転数依の存性は見られない。しかし、回転前は騒音に大きな 差が無かったが、100 時間回転後は 10rps から 30 ps の間では騒 音の差が約 $8.5 \mathrm{~dB}$ になった。

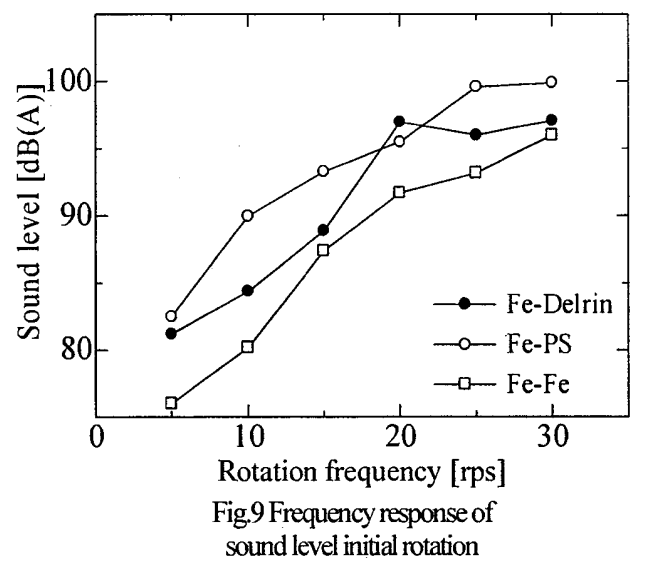




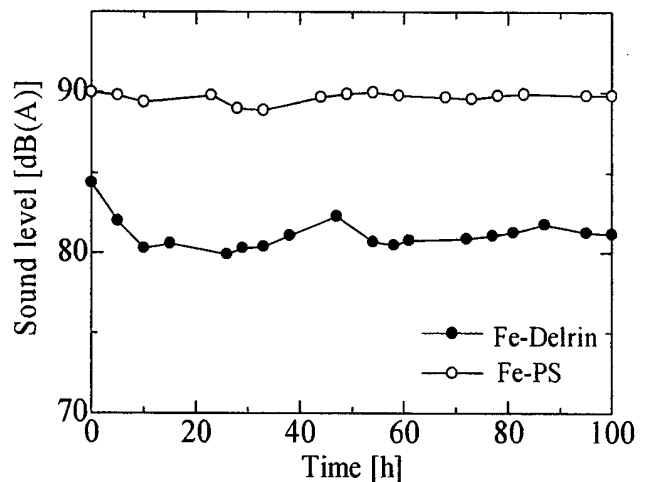

Fig.10 Variation of sound level with time

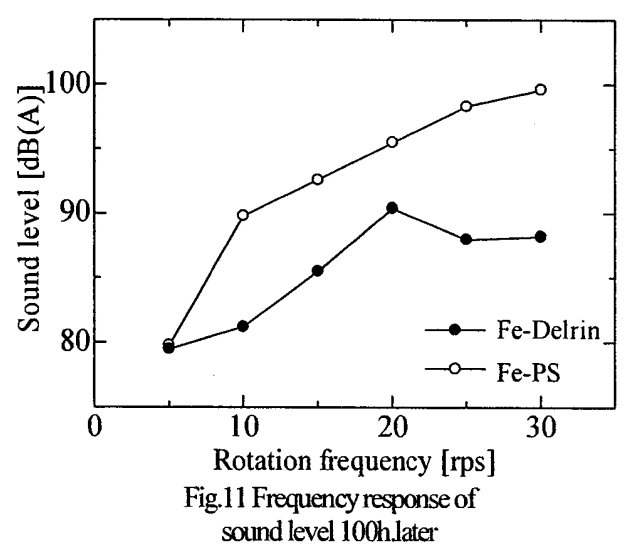

4.2 FFT 解析

本研究で提案した複合蒾車の騒音はプラスチック歯車の騷音 より小さいことがわかるが、周波数分析により周波数特性を調 ベてみる。

図 12 より、プラスチック歯車の音圧レベルは複合歯車に比 べ大きいことが分かる。また、図 13 より、複合歯車の場合、 100 時間回転したあとの音圧レベルは回転前に比べ全体的に下 がっているが、プラスチック歯車はほとんど変化が見られない。

ここで、それぞれの歯車での音質を比較してみる。複合歯 車の場合は、 $1.25 \mathrm{kHz}$ までの騒音が支配的で、それ以上の周波 数での騒音はあまり大きくない。よって、低音が支配的な音質 である。プラスチック歯車の場合は、1.25kHz までの騒音は複 合歯車と同等であるが、 $1.25 \mathrm{kHz}$ 以上の騒音は大きい。よって、 大きな低音に高い周波数の音も混ざっているので、耳障りな音 質である。鋼製歯車は全体の音圧レベルが小さいため騒音は大 きくない。700Hz 近傍の騒音が支配的だが、 $10 \mathrm{kHz}$ 近傍に大 きなピークがあるため、支配的な低音に 1 つ目立った高音が混 ざった音質である。しかし、この高音の音は金属音であり、騒 音レベルは複合歯車より小さいものの、耳障りな音となってい る。以上より、複合歯車は低音が支配的であり、他の音域はあ まり目立たないので、音質は良いと考えられる。
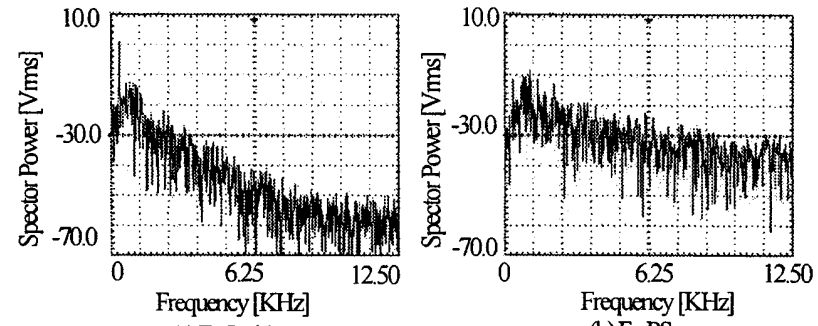

(a)Fe-Delnin (b) Fe-PS

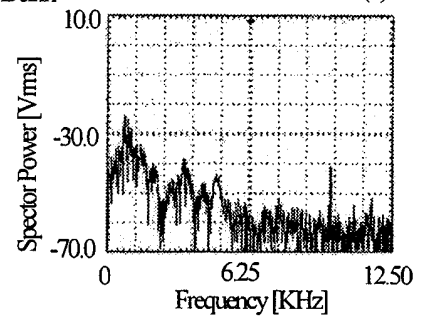

(c) Fe-Fe

Fig.12 Frequency spectrum for sound levels (Rotation frequency $=15 \mathrm{rps}$ )

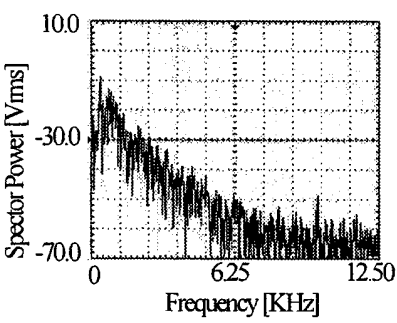

(a) Fe-Delrin(100hlater)

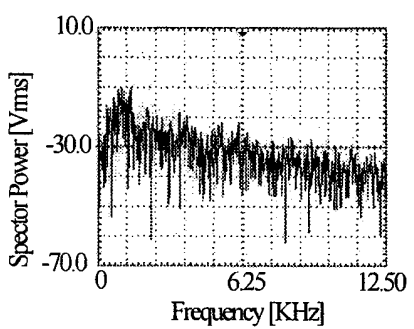

(b) Fe-PS(100hlater)
Fig.13 Frequency spectrum for sound levels (Rotation frequency $=15 \mathrm{~ms}$ )

\section{5. 複合歯車の位置決め制御における摩擦特性}

無潤滑歯車は一般に潤滑歯車にくらべ、摩擦が大きくなる。 摩擦が大きくなると、スティックスリップが発生したり、位置 決め制御においては、振動低减効果があるものの摩擦力が復元 力より大きくなると、そこで停止するので、定常偏差が発生す る。以下、このような観点から本複合歯車を用いた系の位置決 め制御を行い、プラスチック歯車などの場合との比較検討を行 う。

図14は比例制御（P制御）の結果を示す。プラスチック歯車 は摩擦力が大きいため減衰が大きく、最も早く振動が減衰して いる。逆に鋼製歯車は油で潤滑して摩擦が小さいため減衰が小 さく、最も遅く目標值に収束している。複合歯車はプラスチッ ク歯車と鋼製歯車の中間の特性を示している。図15は比例制御 の場合の複合歯車、プラスチック歯車、鋼製歯車の定常偏差を 比較したものを示す。プラスチック歯車の場合、全体的に定常 偏差が大きいことが分かる。鋼製歯車の場合、潤滑しているの で定常偏差は小さくなると思われたが、それほど小さくないこ とが分かる。複合歯車の場合、多少のばらつきはあるものの最 も定常偏差が小さいという結果が得られた。位置決め制御など においては、定常偏差が制御系の性能を支配する指標ともいえ るので、複合歯車は位置決め制御に関して最も良い結果が得ら れたといえる。 


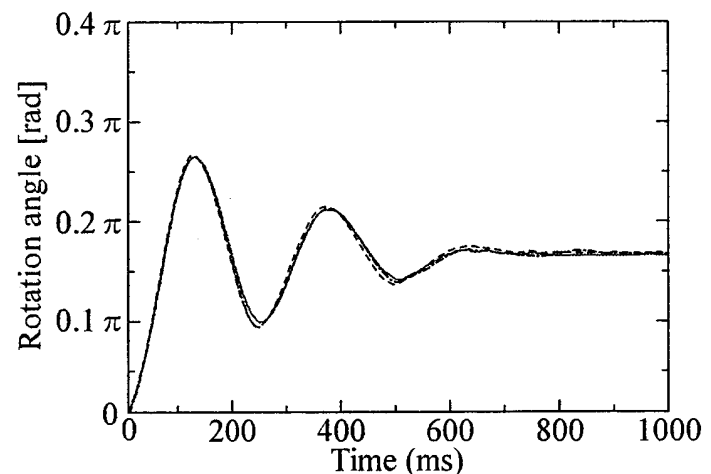

(a) $\theta=\pi / 6, \mathrm{Kp}=20, \mathrm{Kv}=0$

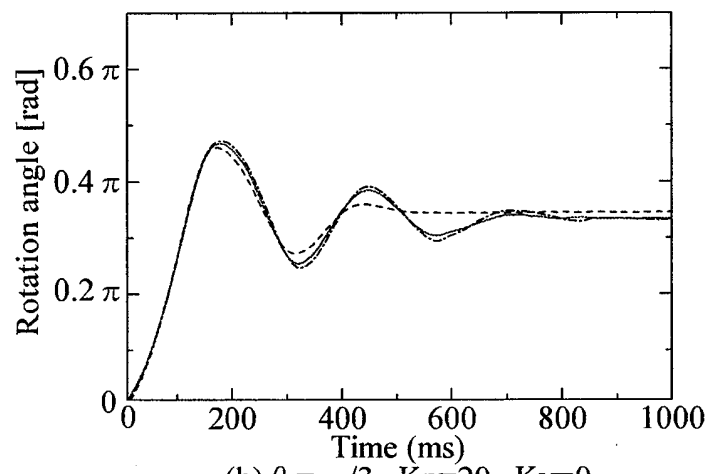

(b) $\theta=\pi / 3, \mathrm{Kp}=20, \mathrm{Kv}=0$

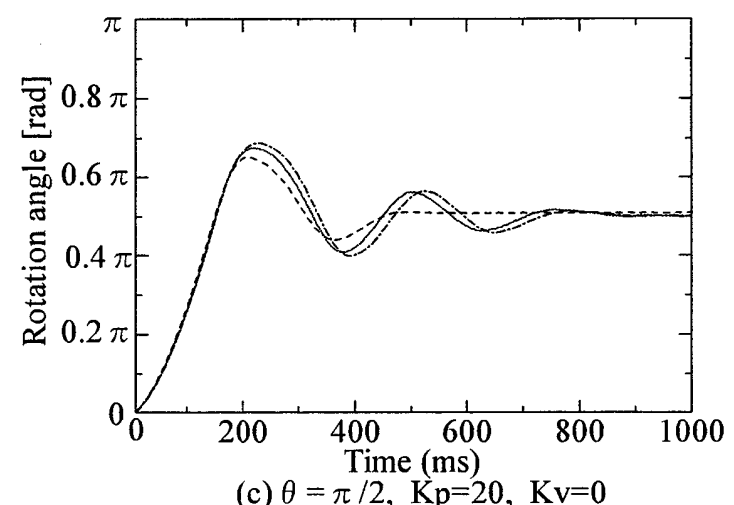

Fig.14 Step response for the angle under P-control

(—:Delrin ------:Plastic —:Steel)

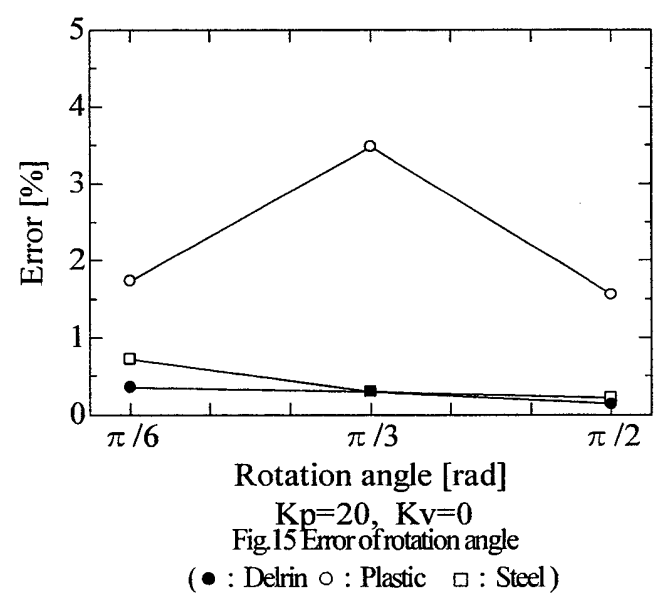

\section{6. 結言}

本研究では、無潤滑低騒音かつ耐衝撃性の優れた歯車機構と してDelin樹脂および金属複合歯車を提案し、実際に製作して 実験によりその妥当性を検証した。その内容を要約すると、

(1) 騒音抑制と無潤滑およひ渜衝擊性の向上の見地から、Delin 樹脂と金属による複合歯車を試作した。

(2) 本研究て提案した複合歯車と、従来用いられているプラス チック歯車について、騒音特性を調べたところ、複合歯車の騒 音はプラスチック歯車の騒音に比べ小さいことが分かった。

(3) プラスチック歯車の騷音は減少することはないが、複合歯 車の騒音は、使用時間とともにいずれの回転数に対しても騷音 が下がっていることが分かった。

(4) 固有振動数の音圧レベルのピーク值が複合歯車の場合、鋼 製歯車よりも約10Vms小さいことが分かる。これは、複合歯車 は減衰があるため、音圧レベルが小さくなったと考えられる。

（5）複合歯車の応答特性は、PS歯車と鋼製歯車の中間であるが、 制御系の性能を支配する指標ともいえる定常偏差は最も小さい ということが分かった。

(6) 本研究で提案した複合歯車は実用性の観点から考えても有 用であると言える。

\section{7. 参考文献}

[1] D. Walton, A. B. Cropper, DJ. Weale, P. Klein Meuleman, The efficiency and friction of plastic cylindrical gears, Part 1: Influence of materials, Proceedings of TMECHE Part J, Joumal of Engineering Tribology 216, No.2 (2002), 75-92.

[2]D. Walton, A. B. Cropper, D.J. Weale, P. Klein Meuleman, The efficiency and friction of plastic cylindrical gears, Part 2: Influence of tooth geometry, Proceedings of IMECH Part J, Journal of Engineering Tribology 216, No 2 (2002), 93-103.

[3] M.Kurokawa, Y.Uchiyama, T.Iwai, S.Nagaai, Performance of plastic gear made of carbon fiber reinforced polyamide 12, Wear, Vol.254, No.5 (2003); pp.468-473.

[4]T. Hirogali, E. Aoyama, T.Katayama, S.Iwasaki, Y.Yagura, K.Sugimura, Design systems for gear elements made of cotton fiber-reinforced plastics, Composite Structures, Vol.66, Issues 1-4, (2004), pp.47-52.

[5] M.Murakawa, T.Komori, S.Takeuchi, K.Miyoshi, Performance of rotating gear pair coated with amorphous carbon film under a loss-of-tubrication condition, Surface \& Coating Technology, Vol.120,(1999), pp.646-652. [6]大谷杉郎, 驚異の炭素, 中央公論事業出版 [7]熱硬化性樹脂組成物，特許公報，(1999-4)，第 2879150 号 [8]長屋幸助・高橋則昭 - 戸上和幸 - 久米原宏之 - 大西章雄, 無潤滑低騒音歯車の開発，日本機械学会論文集(C編), 69巻, 681 号, (2003-5)

[9]日経メカニカル 1998.8 No.527p.p.100-109

[10]倉西正嗣, 機械要素設計, オ一ム社

[11]入戸野修, 材料の科学々工学 4 , 培風館

[12](社)精密工学会 成型プラスチック歯車研究専門委員会報

告書（2003 年度）,(2004). 